古代ギリシャにおける Gymnasion の所在とその 分布

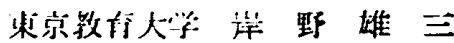

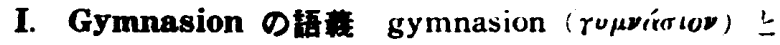

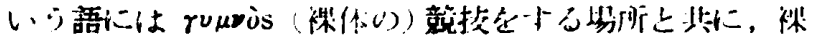

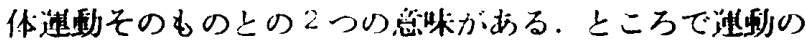

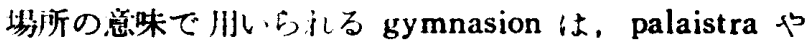
stadion との類似語之区別があり，この問䞨については 今だに論㦈されており，発堀調査の報告によれば，特に stadion は gymnasion 上離れた位置にあることが多か つた。しかし、ヘレニズム時代の gymnasion の発展を

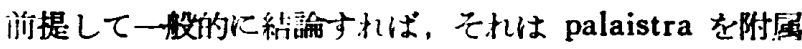
施設上し，Stadion の機能をも有した総合競技場であつ たといえる。

II. Gymnasion の機能の友的变逼|のような说 明は，しかし，体危の晹からのてれであり，gymnasion は運動競技を越えた社全的㙨能を增していくし たがつて原来が競技苦の練習場之しての機能から，それ

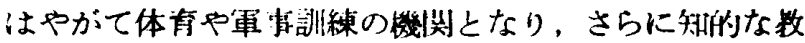

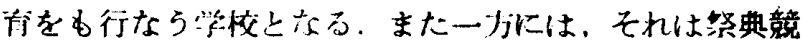

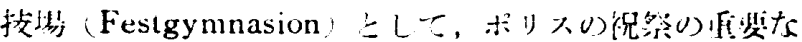

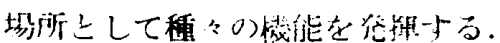

\section{Gymnasion に附せられた名称の多梾性}

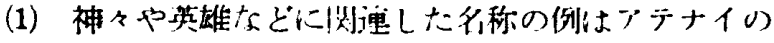
Hermes-gymnasion. $t+7$.

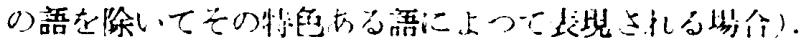

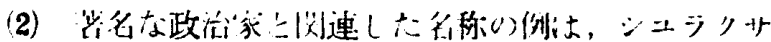

ケの Timoleonteion gymnasion t悇いた侧) 怘ど.

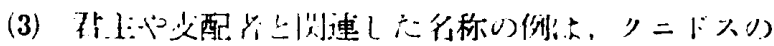
Antigoneion

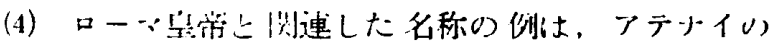
Adrianeion-gymnasion など.

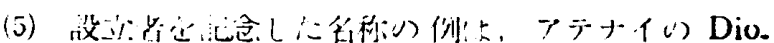
geneicn, ス八ル夕け Euryklesgrymasicn ‘と.

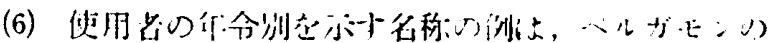
gymnasion ton paidon, $ス \therefore ん$ gymnasion ton ephobon liai ton neon is

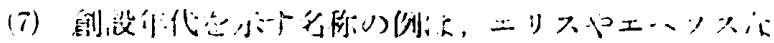

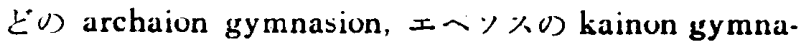
sion t大.

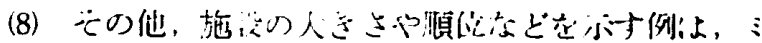
レトスの mega gymnasion や少 $ミ$ スの triton gymnasionながある。

\section{Gymnasion の际在の脂代的望理}

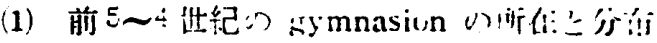

・ギリシブイ゚:-- Athene. Akademeia. Lyliuun. Cynosarges $\sigma$ agym. Kerintho., Nemea, Truizen, Elis, Spalta, Thebai, Delphui. Pherai (Thessalia), Byzantion (Thracia).

・エーダ锗息-Delos palaistra のみ， Thera, Ko resia Keos: Thasos, Oreos Euboia : Phodos?.

-j、棌-Ephesos, Iasos, Mylasa.

- そり(也-Naukrates (Egypt), Syrakusai Sicily).

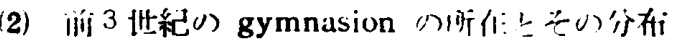

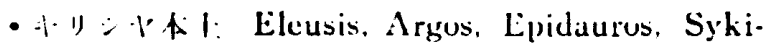
on. Ulympia, Larisa (Thessalia), Pharsalos. Diun (Makedonia).

・エーケ謀岛ーDelos, Astypalair, Kcos, Paparethos,

Chios, Kos, Lesbos, Samos, Rhodos. Kition (Kypros).

・小アジアーAbydos, Iasos, Halicarnasos, Miletos,

Smyrna, Teos, Laodiceia (Phrygia).

・エジフトーAlexandria, Louqsor. Philadelphia, Samareia.

・シリアーAntiochia.

•オクシデ:ト-Catane, Netum. Tyndaris (以.L. 访在: Sicily), Tarentum (Italy), Capua (Italy).

(3) ijij 2 訨紀の gymnasion の所在とその份布

・ギリシア本土ーAthene (Diogeneion, Ptolemaion).

Anthedon, Demetrias, Herakleia Tracheia, Sestos (Thracia).

・エーゲ諸勘-Delos. Andros, Arcesine Amorgos), Chalcis, Eretria, Melos, Paros, Kourion Kypros), Kerynia (Kypros).

-小アジーAigai, Apameia-kibitos, Aphrodisias (Caria), Apollonis (Lydia), Assos (Mysia), Kolophon, Karayuk-bazar, Magnesia (Maiandros), Magnesia (Sipyle), l'ergamon, Priene, Sardis, Synnada, Theangela. Thyateira.

•メシン 1-Ombus. Pharbaithos, Ptulemaios, Theadelphia.

- ぞの优-Histria (Pontos Euxinos:, Antiphellos (Lycia), Kyane:a (Lycia). Mupsueste (Cilicia) Pe. rge (Cilicia). Salamis(kypros), Jerusilem (Syria), Laudilicia (Syria).

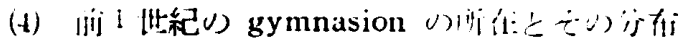
・ジリア本1:-Aigion, Kardamyle Messenia), Mantincia, Akraiphia, Chaironeia, lulkus. Opunte.

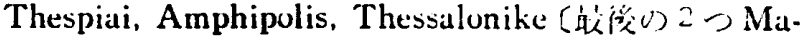
cedonia].

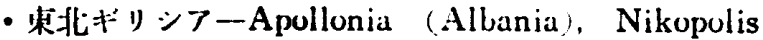
(Epiros).

-エーケ䜅島-Amurgus, Aegina, Mytilene, Suriphos.

-小アジーAlabanda, Bargylia, Knidos, Kymai ( Lioris), Kyzikos, Nikaia, Nysa (Maiandros), Stratonikeia (Caria), Tarsos. Tralleis.

- 黑海岸-Kallatis, Phanagoria. Sinope.

- ニジブー-Aphroditopolis, Kyrene (Africa)

- $\therefore$ つ他-Capri. Etna, Leontinui, Neapolis (以 I: 1

2 Sjria).

かくて gymnasion はへレニズ時代には将りシア市 土よりも東方に発展し，特にべルガモンなどの小アジフ に比大な施教か建てられ，口-了時代には西方に拉大さ んていつた. 